\title{
Jobofifetime
}

\section{Making sure fair use gets a fair shake}

Tf you think "intellectual property" (rather 1 than address) when someone mentions IP, find Congressional hearings to be fascinating reading material, and enjoy advocacy, then being the ALA copyright specialist might be your job of a lifetime. Carrie Russell has held that post in ALA's Washington, D.C., Office for Information Technology Policy (OITP) since 1999. "The OITP promotes policies and programs that help ensure the public's right to a free and open information society."

\section{Open for interpretation}

I was immediately curious to know what a copyright specialist does and whom they serve. Russell explained, "I primarily work for ALA members and other librarians. Most of my job is devoted to educating librarians about copyright. I think we have made a lot of progress in getting librarians

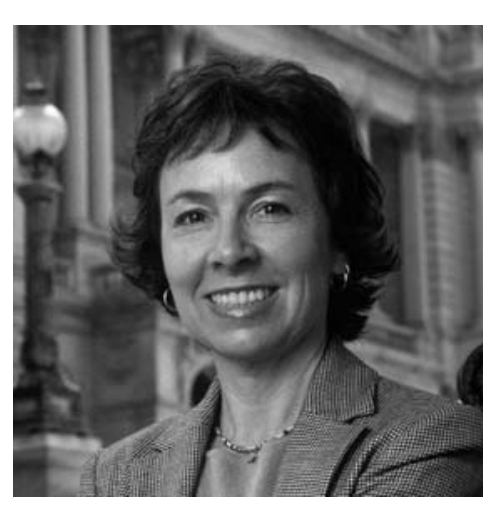

Carrie Russell, copyright specialist for the ALA Office for Information Technology Policy

\section{D.C. work}

Russell categorized part of her job as the "D.C. work." "I conduct policy analysis on copyright, information commons, and, to a lesser extent, digital rights management. I look at new developments that people are talking about on the Hill and at the federal level. I think about what it might mean for copyright and libraries if something comes to pass. For example, peer-to-peer file sharing has led to legislation and litigation that impacts libraries, even though peer-to-peer doesn't seem directly related to libraries. Once I identify an issue, I focus on it and track it. I do a lot of reading of what other people are saying-what's their take on the topic-and try to make an overall analysis."

"We also work as a think tank," Russell added. "We're not Brookings or anything like that but we're supposed to be thinking about what's on the horizon, so we hold meetings with experts like economists, technologists, and other folks we want to hear from. Any new information I glean from these discussions, I share with our lobbyists because they're the ones who actually have to talk to the decision makers, the congresspeople, and their staffs. I will say, 'This is what's really

Danianne Mizzy is assistant head of the Engineering Library at the University of Pennsylvania. Have an idea for a "Job of a Lifetime" story? E-mail: danianne@seas. upenn.edu. 
happening and this is how it would impact libraries.' It's behind the scenes research."

\section{Making the complex clear}

One of the things Russell finds rewarding about her job is the opportunity to write.

"I am very happy when I can write something well. I never knew how much I enjoyed writing until I worked here. I like taking something complex and writing about it in a way that people can understand. Take the DMCA. There's a lot of noise in it, a lot of stuff that doesn't matter to us. There are just a couple things that are important for librarians." She is the author of Complete Copyright: An Everyday Guide For Librarians and also pens a copyright advice column, "Carrie On Copyright," for School Library Journal, where she answers selected questions from readers. She's also been teaching an online seminar for ACRL, "Current Copyright Issues Facing Academic Libraries."

OITP is ramping up its own Copyright Advisory Network, an idea that was generated by the Copyright Advisory Committee. Russell described how it works. "People who have a copyright question or concern can go to the Web site, sign up to be part of the network, and then post their question anonymously to the bulletin board. Other network members write back with a range of responses. People begin to understand that copyright is interpretive and that eventually they and their particular institutions are going to have to assess where they stand. Are they risk-averse or do they want to push the envelope? If they want to push the envelope, they can learn about people's success stories or challenges on the network." She is hoping to increase the number of copyright scholars contributing opinions to the site.

\section{The good fight}

When I asked what people might be most surprised to learn about her job, Russell had a very interesting response. "I think people have a misconception about D.C.-it really is a different world 'inside the beltway.' We have to be very political, very strategic about every move. We have to work with the Executive and Legislative branches, whomever is in office. Sometimes we have to do things that look from the outside as if we're caving in and not fighting 'the good fight.' A U.S. senator may say something outrageous and I think sometimes librarians would like us to march out the door, stage a protest, and march down Pennsylvania Avenue in outrage. If we reacted that way, we would lose all credibility and we would not affect change. It can be very frustrating, but you have to play the game."

\section{See you at Legislative Day!}

Russell spoke passionately about the role of librarians at the local level. "They can have a great impact. I always remind people that as a resident of the District of Columbia, I don't have senators or representatives. I have taxation without representation! You guys should be writing your congresspeople because they do read those letters.

"It would be great if we could get more librarians to be on the frontline as fair use advocates. I know it's harder to argue for fair use than against banned books, but it's discouraging to hear congressional staff say, 'Why do librarians care about copyright? What does fair use have to do with you?' when in fact libraries are all about copyright law. There are entire sections of the law devoted to us, but congresspeople are not hearing from their constituents."

The next time I receive one of those Washington Office Newsline requests to write my members of congress, I'll be more likely to add my voice to those of library advocates like Carrie Russell. How about you? $\pi$ 